\title{
Early marriage, adolescent motherhood, and reproductive rights for young Sasak mothers in Lombok
}

\author{
LINDA RAE BENNETT
}

\begin{abstract}
This article focuses on Indonesian adolescents who are wives and mothers, demonstrating how early marriage and adolescent motherhood are normative among women from poor Sasak communities in Western Lombok. It is based on ethnographic research with 28 young mothers that included focus group discussions, in depth interviews, and observations. Demographic and ethnographic data on the aetiology of early marriage and adolescent motherhood are discussed, and confirm that low educational attainment for girls, lack of employment prospects, poverty, and low levels of economic development are all associated with a higher probability of adolescent marriage and motherhood in Indonesia. The article also reveals how conservative sexual morality and local marriage customs can propel girls into early marriage. It provides a human rights analysis that demonstrates how early marriage and adolescent motherhood intersect with the neglect of girls' rights to education, employment, equality in marriage, health information, family planning, and maternal health.
\end{abstract}

KEYWORDS

Indonesia, early marriage, adolescent mothers, reproductive rights, maternal and child health.

\section{INTRODUCTION}

This special edition of Wacana on Indonesian youth makes an important contribution to highlighting the diversity of identities and experiences among children and young people in Indonesia. Much of the published literature

LINDA RAE BENNETT is a medical anthropologist and senior researcher in youth and reproductive and sexual health at the Nossal Institute for Global Health, The University of Melbourne. Her publications include: "Women and gender politics in Asia and the Pacific" (2012), in: Intersections; Gender and Sexuality in Asia and the Pacific 28: 1-4, with P. Mahy; "Body, sexuality, and gender among contemporary Indonesian youth" (2008), in: Intersections; Gender and sexuality in Asia and the Pacific 18, with Lyn Parker; Women, Islam, and modernity; Single women, sexuality and reproductive health in contemporary Indonesia (Routledge, 2005). Linda Bennett may be contacted at lbennett@unimelb.edu.au. 
on Indonesian youth to date has been focused on young people who are still participating in education (Parker 1997, 2009; Nilan et al. 2011), who are still living under the care of their natal families or other relatives (Bennett 2005), and who have the economic means to participate in highly commodified and increasingly globalized youth cultures (Beazley 2008; Luvaas 2009, 2010; Nilan 2008). The young people who have typically been the subjects of social research in Indonesia have tended to be middle class, unmarried, viewed as still dependent upon their natal families and pre-adult in their social status. There is also a smaller body of social research that deals specifically with disadvantaged youth, and in many cases youth who are considered "deviant" according to the norms of Indonesian society. This research includes studies of Indonesian street children (Beazley 2003), child and youth sex workers (Safika 2009; UNICEF 2004), and children who are vulnerable due to poverty and migration (Beazley 2010). This article extends the boundaries of existing youth research in Indonesia to look at young people who are not in school, who are from poor rather than middle class backgrounds, and who already occupy adult roles and status despite their young age. The youth whose lives feature in this article are not considered deviant within their own communities, despite their sexual debut at an early age, because they are typically married when they became sexually active. The present research focuses on the issues of early marriage and adolescent motherhood as experienced by young Sasak mothers from impoverished communities in Western Lombok. ${ }^{1}$ The Sasak youth involved in this research were all married between 14 to 19 years of age and thus were simultaneously teenagers and wives, and all subsequently became mothers by the age of 20. Examining the lives and experiences of adolescents who are also wives and mothers fills an important gap in existing perspectives on Indonesian youth.

Popular attitudes toward early marriage and adolescent mothers that circulate in the Indonesian mass media and public discourse are rarely complimentary. There is a general moral panic about teenage sexuality globally and most certainly in Indonesia, where pergualan bebas (free courtship) and seks bebas (free sex) are seen as constituting a tangible and monumental threat to young people (Harding 2008; Wright-Webster 2010). The public perceives teenage pregnancy to be a consequence of premarital sex, despite the reality that early marriage is such a common phenomena in Indonesia and the fact that the vast majority of adolescent mothers are married when they become pregnant.

A brief online search of the key terms - early marriage, adolescent motherhood, and teenage pregnancy in Indonesia was conducted to identify

1 I wish to thank the following people and institutions for their generous contributions: all the young Sasak mothers who shared their time and stories; the expert key informants in Lombok - particularly Ibu Kas and Ibu Rahmi; Korporasi Annisa for their ongoing support; Eni for her diligent transcription of FGDs; Ani and Desi for providing childcare for the children of young mothers; the Ambivalent Adolescence in Indonesia project team; and the Australian Research Council for the discovery grant that financed the research. 
popular stereotypes of young Indonesian mothers that circulate on the internet. The four key messages conveyed in these materials were that: adolescent mothers are victims; adolescent mothers are the vectors of disease; teenage pregnancy reflects the moral decay of Indonesian society and the intrusion of inferior Western values; and that early marriage and adolescent pregnancy are shameful. For instance, the Jakarta Globe reported "Pregnant teens still face stigma, isolation, even death" (7 June 2010), while Satu Dunia ran the following headline "Pregnant teenagers, the consequences of free sex, high risk of spreading HIV" (2 April 2009). Recent in-depth investigations of popular Indonesian attitudes towards adolescent sexuality conducted by Harding $(2007,2008)$ and Wright-Webster (2010) confirm the negativity of stereotypes associated with teenage sexuality and adolescent pregnancy in Indonesia.

Below, I offer an analysis of early motherhood and the experiences of adolescent mothers in Indonesia that reveals how popular stereotypes are largely inaccurate and irrelevant to the identities and experiences that are narrated by young Sasak mothers themselves. The approach adopted in my presentation of field data has two key characteristics. First, I explicitly seek to privilege the perspectives of young mothers when seeking to understand why they marry and have children at an early age. Second, I analyze the interconnected phenomena of early marriage and adolescent motherhood from a human rights perspective.

11 October 2012 was the first International Day of the Girl Child, an initiative of the United Nations General Assembly that was widely supported around the globe. A primary focus of this initiative is the abolition of child marriage, which is defined as a formal marriage or informal union before the age of 18 . This global movement explicitly recognizes child marriage as a human rights violation that impacts widely on girls' and young women's lives (Svanemyr et al. 2012). While there is now widespread recognition that early marriage and motherhood are inextricably interconnected with the neglect of young women's human rights, there is relatively little published work examining how the neglect of human rights relates to the determinants, impact and experiences of adolescent marriage in specific communities. In this article, I develop a human rights analysis that includes young women's reproductive rights as an integral and interconnected aspect of their overall human rights.

This article is based on five months of ethnographic fieldwork, conducted between July 2008 and August 2009, and builds upon 17 years of researching reproductive health issues among Sasak women. Initially, I provide some background information on the extent of early marriage and adolescent motherhood in Indonesia in general, and in the research site of Lombok more specifically. This section also presents the conclusions of available demographic analyses of the factors strongly associated with an increased likelihood of women reproducing at an early age in Indonesia. After a brief discussion of my methodology, including a description of the young Sasak mothers who contributed to the study, I proceed to examine the aetiology 
of early marriage in Lombok from the perspectives of young mothers. Their perspectives clearly indicate that entrenched poverty is the overarching factor constraining their life options and supporting their choice to marry early. Having established the centrality of poverty in determining young women's life trajectories, the next section of the article discusses exactly how the distinct and overlapping rights to education, employment, and marriage are being neglected for this group.

I then turn to explore the synergy of early marriage and adolescent motherhood for young Sasak women by examining the varied motivations they have for reproducing without delay, and the contrasting lack of incentives for delaying motherhood. Once the importance of motherhood among these women has been determined, I describe the health of young Sasak mothers and their children, including their reported interactions with maternal health services. I then turn to a discussion of young mother's rights to health information, family planning and maternal health, reflecting on how their reported engagement with the maternal health system has both satisfied and neglected these rights in different contexts.

The article concludes with a summary of my theory on the aetiology and synergy of early marriage and adolescent motherhood for poor Sasak women in Lombok. It also reiterates the importance of human rights approaches to addressing these issues, focusing on the right to non-discrimination in health care and the need to recognize the interconnectedness of reproductive rights with other human rights. My final comment is a call for integrated interventions that view early marriage and adolescent motherhood as stemming from complex and systematic disadvantage. This approach should shift the "blame" away from individuals and towards the recognition that whole communities, and the governing bodies responsible for promoting their welfare, need to participate in the prevention of early marriage and teenage pregnancy.

\section{BACKGROUND}

Extensive research into early pregnancy and childbearing has established the considerable health risks for both mothers and babies when women become pregnant under the age of 20, and that these risks are more pronounced for women who conceive before the age of 17 (McCauley et al. 1995). In addition to the myriad of negative health consequences related to early childbearing, there are also long term social and economic costs to women who become mothers during adolescence (Choe, Thapa, and Achmad 2001). However, early childbearing and adolescent marriage has received limited academic and government attention in Indonesia until recently following an explicit commitment to address Millennium Development Goal 5 (Specifically Target 5.B - Achieve by 2015 universal access to reproductive health) by attempting to reduce Indonesia's adolescent birth rate (Nasril and Samosir 2011). ${ }^{2}$

2 This is with the exception of a few notable works including commentary on historical and political debates over early motherhood in Indonesia by Blackburn and Bessell (2007) and 
Recent demographic analyses conducted or endorsed by the Government of Indonesia (GOI) have begun to shed light on patterns of early marriage across the nation. Through analyses of the 2007 Indonesian Demographic Health Survey (DHS), Desriani (2011) confirmed that the prevalence of teenage motherhood among women aged 15 to 19 years was $50 \%$ in a sample of 845 women, and that the prevalence of teenage motherhood among adult women was $60 \%$ in a larger sample of 29,959 older women. While these findings indicate a $10 \%$ reduction in the prevalence of the teenage motherhood, which is consistent with a gradual increase in the age of marriage across Indonesia, it still highlights that early marriage and adolescent child bearing are not rare but rather are normative among Indonesian women from poor backgrounds. Moreover, as the DHS does not include women under the age of 15 or unmarried women, real rates of early marriage and adolescent motherhood may well be underrepresented in DHS data.

Further analyses of the 2007 DHS data have yielded insight into the determinants of adolescent motherhood among young Indonesian women between the ages of 15 to 19. Nasril and Samosir (2011) found that women's level of education, their employment status, their husbands' employment status, and their place of residence all had a statistically significant impact on the odds that married teenagers would become mothers during adolescence. Among a sample of 845 married adolescent women (aged 15 to 19), those who had not completed primary school were three times more likely to become mothers during their teen years. They were also three times more likely to become pregnant during adolescence if they were unemployed, and 2.5 times more likely to become pregnant if their husbands were unemployed. Finally, Nasril and Samosir (2011) reported that young married women living in rural areas were 1.4 times more likely to experience teenage pregnancy than their urban counterparts. ${ }^{3}$ These findings in Indonesia are consistent with previous international studies that have focused on early motherhood in poorly developed settings, and iterate the widely accepted understanding that low formal education for girls, limited employment opportunities, and residence in rural and remote communities all escalate the risk of early marriage and adolescent motherhood (Choe, Thapa, and Achmad 2001). In other words, early marriage and motherhood are strongly associated with poverty and low levels of development.

The young Indonesian mothers whose experiences feature in this article are of Sasak ethnicity and all are Muslim. The Sasak are the indigenous inhabitants of the eastern Indonesian island of Lombok, and constitute around $90 \%$ of the island's population of approximately 3.5 million people.

demographic work on age of marriage by Jones and Gubhaju (2008), as well as a comparative study of early marriage and motherhood between Nepal and Indonesia by Choe, Thapa, and Achmad (2001).

Similar findings were also produced by Prasetya and Dasvarma (2011), who analyzed data from the 2007 Indonesian Youth and Young Adult Reproductive Health Survey (IYARHS) and concluded that low levels of education was the strongest predictor of adolescent motherhood among women in their sample. 
While they make up the majority of the population, the socio-economic and political marginalization of the Sasak is a well-documented reality (Grace 1997; Judd 1980). Lombok is characterized by a comparatively low level of development relative to elsewhere in Indonesia, and early marriage and child bearing amongst rural Sasak has persisted for longer than is the case among other ethnic groups from neighbouring islands. Indonesia's national Human Development Index (HDI) in 2005 was 0.728, giving it a rank of 107 out of 177 countries (UNDP 2007), while the HDI for Nusa Tenggara Barat (NTB) province (where Lombok lies) was estimated to be significantly lower at 0.587 in 2007 (MOH 2008). Moreover, maternal and child mortality rates for the province of NTB have remained higher than in other regions, despite decades of bilateral aid and national intervention programs targeting these problems. ${ }^{4}$ According to the 2007 DHS, the infant mortality rate for NTB is 72 deaths per 1,000 live births, while the national average was reported as 39 deaths per 1,000 live births (BPS and Macro International 2008). The tendency of the Sasak to marry earlier than other ethnic groups in Indonesia is well noted, and evidenced by recent research into reproductive rights in NTB, which indicated that $40 \%$ of a sample of 504 women had been married before the age of 18 and that $23 \%$ of 504 women had given birth to their first child by the age of 18 (Bennett and Andajani-Sutjahjo 2007). Lower development and high rates of early marriage and adolescent motherhood make Lombok an ideal location for observing the experiences of young Indonesian mothers and for exploring the determinants of early marriage and motherhood.

\section{METHODS}

Twenty-eight young Sasak mothers aged between 15 and 25 participated in this qualitative study. Their ages at first marriage were between 14 to 19, and 24 out of 28 women resided with their husbands. Four young mothers had divorced and all had returned, accompanied by their children, to live with their own parents. The majority of women were living with their husbands' in-laws as is customary on the island, and none of the women represented in this research were living as independent single mothers, as is more often the case in Western societies. The age at which these young mothers delivered their first child ranged from 14 to 20 years, and they had given birth to a total of 31 children, of whom 27 were still alive.

All of the women in this study were from impoverished families, regardless of whether they resided in urban or rural communities. Their monthly household income ranged from zero cash up to one million rupiah per month, with the average lying between 400,000 and 700,000 rupiah. Only two women were able to describe their husband's employment as secure and ongoing. Many described significant periods of economic hardship due to regular cycles of unemployment resulting from the contract nature of construction work and the seasonal nature of agricultural labour. Six out of 28 young mothers had

\footnotetext{
$4 \quad$ The persistence of high child mortality on Lombok has been a subject of significant inquiry, for details see Rusman, Djohan, and Hull (1999).
} 
participated in paid work since the birth of their children. Their occupations included working as a domestic servant, as a laundry attendant, cooking for a small food stall, wrapping snacks, hauling sand and rocks, and planting rice seedlings. None of these jobs generated more than 20,000 rupiah per day.

The educational attainment of young mothers was low, although all were literate. Sixteen young mothers had left school at primary level, indicating a serious shortfall in Indonesia's current national education policy of assuring a minimum of nine years schooling, or the completion of junior high school, for all citizens (Jones and Hagul 2001). A further twelve women had begun junior high school, and of these eight had graduated. Out of the eight who had graduated from junior high, only four were successful in completing senior high school. While I do not discuss young women's educational aspirations in detail due to space restraints, it is important to highlight, that every young mother I spoke with asserted the desire to be more highly educated. The educational levels of these women's husbands tended to be parallel with or slighter higher than their wives.

Where I have integrated direct quotes from young mothers, I have their explicit consent to do so, and have used pseudonyms to protect their identities. The young mothers who participated in this research were recruited from three communities situated in the municipality of West Lombok, ten resided in the urban environment of Mataram and 18 lived in two nearby villages. Women who had become mothers by the age of 20 were invited to join the research through advertisements posted at primary health clinics, community birthing huts and a community-based organization $(\mathrm{CBO})$ that conducts literacy and education programs for young women. ${ }^{5} \mathrm{My}$ initial contact with young mothers was at focus group discussions. Most mothers were accompanied by their children, and so the discussions were highly informal, punctuated by children's chatter, demands for their mothers' attention, and disputes over toys or snacks. At the end of each group discussion, one mother was nominated by the group as a contact person responsible for linking up myself with anyone who wished to meet again for the purposes of an interview. Using a go-between is culturally familiar in Lombok and allows people to decline invitations without losing face or being concerned about causing offence to the "outsider". The outcome of this strategy was that 23 out of 28 women chose to participate in in-depth interviews, and many chose to be interviewed multiple times. Focus groups were conducted in Indonesian, and interviews were conducted in a mix of Indonesian and Sasak. In addition to my dialogue with young mothers, I also spoke with nine expert key informants, including: three bidan (government-trained midwives); two school counsellors; two CBO staff and two development consultants working in the area of maternal health. Fieldwork also included observations of young mothers in their homes and while attending skills-building classes at a local CBO.

The CBO I refer to here is Korporasi Annisa, based in Mataram, which is a local grass roots group with 20 years of successful programs that have targeted Sasak women's rights, skills, education, and status in the family. 


\section{WHY MARRY EARLY?}

While research in a variety of cultural settings indicates that premarital pregnancy can be a leading cause of early motherhood in impoverished communities, this is not the dominant pattern for young mothers in Lombok (Biddlecom et al. 2008; Grant and Hallman 2008). Conservative sexual norms and constant social surveillance of women prior to marriage mean that the majority of young Sasak women will be married when they fall pregnant with their first child, and virtually all will be married before the child's birth. ${ }^{6}$ The answer to why poor Sasak women continue to become mothers early is largely explained by the fact that they continue to marry early. Thus, teasing out the causal factors behind early motherhood requires us to examine persisting patterns of adolescent marriage in Lombok. Four common responses were repeatedly articulated when I asked my informants: "Why do Sasak women, including yourself, tend to marry and have children early?" Women's responses, in order of frequency, were:

1. sudah berhenti sekolah (had already quitted schooling)

2. tidak ada pekerjaan (there was no work available)

3. tidak ada kegiatan lain (there was nothing else to do)

4. harapan hidup sederhana, nikah dan punya anak sudah cukup (simple life aspirations, to marry and have children is enough).

Each of these replies relates to the overarching problem of entrenched poverty in Sasak society. Applying a grounded theory approach, I investigated the significance of different responses to individuals' decisions on when to marry in later interviews. When I inquired as to whether women would have preferred to continue their education prior to marrying, every woman answered in the affirmative. Lack of financial resources was the reason given by all the young mothers I interviewed for ending their schooling before they wished to. The dearth of suitable employment options for young mothers stems from their low levels of formal education and restricted skills, and endemic unemployment on the island. The types of paid employment available to poor young mothers typically yield very low economic benefits. When there are seemingly insurmountable barriers to participation in education and paid work for poor adolescent women their experience is that there is literally "nothing else to do". There are no highly valued alternative social roles available to these women other than becoming a wife and mother. Young women adopt a pragmatic attitude towards their life aspirations, they are acutely aware of the constrained options that flow on from poverty, low educational attainment and limited work skills. Thus, to seek a simple life (hidup sederhana) where marriage and motherhood are achievable aspirations is an entirely understandable and realistic response.

Another motivation for early marriage that stems from entrenched poverty

6 See Bennett (2002) for a detailed discussion of the social surveillance of young women during their courtship and how single women seek to subvert this surveillance in Lombok. 
is the potential economic benefits of a "good" marriage. Parents may wish their daughter to marry early if she has found a prospective spouse who is economically attractive, as they do not wish the possibility of their daughter achieving economic safety to be passed by. Young single women in Lombok are often explicit that financial stability is an ideal characteristic in a spouse (Bennett 2005). This concern over their economic future is a pragmatic necessity, often expressed in the rhetorical question: Jika laki-lakinya belum mampu, nanti anak saya makan apa? (If the man cannot provide, later what will my children eat?) One young mother, Rohun, relayed how her husband proposed to her in the following way:

“Why don't we marry, I have a house of my own, it's empty. Your mother's house if full, there are too many people for her to feed. Why don't you help your mother and become my wife?" (Rohun's husband).

Rohun and her parents were happy to accept this proposal. She married at fifteen and gave birth to her first child at sixteen. Rohun felt very fortunate to find a husband who could provide her with an independent home, and agreed that it did relieve her mother to have one less mouth to feed as there had been thirteen people living in her parents' two-room dwelling before she married. Hence, the financial motivations behind an early marriage are often a desire for basic economic security, rather than imagined fantasies of class advancement.

While endemic poverty is undoubtedly the dominant factor perpetuating early marriage among poor Sasak women, cultural customs and norms also play a role in normalising early marriage. Arranged marriages are rare for poor Sasak women and most choose their own partners. The two most common ways to marry are by the man asking a woman's parents for permission, or via the indigenous custom kawin lari (literal translation 'runaway marriage' or 'elopement'). Nine out of 28 women in this study had participated in kawin lari. Elopement for the Sasak can be sudden and difficult to resist once a woman is stolen (Platt 2012), and women's rights advocates in Lombok have expressed concern that kawin lari may be a form of forced marriage for some women. Among the women I spoke with, three stated that they were not ready to be married at the time they were "stolen" by their husbands, and thus felt that their marriages were forced on them. When I asked them to explain what they meant by forced, each said that they were not ready at that time, but did wish to marry the man in question. It was clear that these women felt they had no control over when they married. Hence, it appears that the custom of kawin lari can contribute to women becoming married young and before they wish to.

An additional factor that can propel women into marriage before they are ready is the hegemonic cultural construction of female sexuality, which insists on female chastity prior to marriage and the confinement of women's sexuality within marriage (Bennett 2005). When young women are thought to be "too close", or to have spent "too much time" with a suitor, or to have returned home "too late" from a date, extremely damaging gossip ensues. This 
gossip distresses and shames girls and their families, and damages marriage prospects. For two women in this study, their marriages were pre-empted by the social censure of their premarital sexuality. Neither of the young women had been ready to marry, but had their nuptials hastened by their parents as a response to negative gossip. They would have preferred to attempt higher education or find paid work before marrying. Thus, the strong moral aversion to premarital sex for women supports early marriage and motherhood among the Sasak. Age politics or when women marry and have children, have far less social significance in these communities than the sexual politics of confining female sexuality to marriage.

\section{THE RIGHTS TO EDUCATION, EMPLOYMENT, AND MARRIAGE}

As noted above, the most common answer to the question "Why do Sasak women, including yourselves, tend to marry and have children early?" was "sudah berhenti sekolah" (I had already quitted schooling). None of the women in this study were married before they left school and all of them were clear that they would have liked to continue their studies if their families had been able to afford further education. All of these adolescent mothers ended their schooling prematurely because of poverty. Participation in education for girls and boys in Lombok is equal in primary school, it then declines for girls during junior high, and drops markedly again for girls in senior high (Bennett and Andajani-Sutjahjo 2007). Research in developing communities across the world has shown that higher levels of formal education for girl children delays both the age of marriage and the age at which women have their first child (Svanemyr et al. 2012). Schools in Lombok do not enrol married or pregnant women, despite a national policy that allows pregnant women to attend school. When we seek a direct lesson from the words of young Sasak mothers, it is clear that their right to participate in formal education is not being recognized and that their decisions to marry early are directly affected by their inability to continue their schooling. Realizing young Sasak women's desire and right to participate in higher levels of formal education - and at equal rates to their male peers - is a key strategy for delaying their age of marriage and the age at which they become mothers.

\begin{tabular}{|c|c|c|}
\hline \multicolumn{2}{|c|}{ YOUNG MOTHERS' EDUCATIONAL ATTAINMENT } \\
\hline $\begin{array}{c}\text { Primary education } \\
(\mathrm{SD})\end{array}$ & $\begin{array}{c}\text { Junior high school } \\
(\mathrm{SMP})\end{array}$ & $\begin{array}{c}\text { Senior high school } \\
\text { (SMA/SMK) }\end{array}$ \\
\hline 16 out of 28 women & 8 out of 28 women & 4 out of 28 women \\
\hline
\end{tabular}

Table 1. Educational background of the participants.

The second and third most common responses to the same question were "tidak ada pekerjaan" (there was no work available) and "tidak ada kegiatan lain" (there was nothing else to do). Six out of 28 young women had undertaken paid work, but not one had worked in the formal sector or had earned over 20,000 rupiah per day. Unemployment rates (for the formal sector) in 
Indonesia are higher among the rural and urban poor, higher for people with lower education, higher for youth and higher for women (Suryadarma, Suryahadi, and Sumarto 2005). It figures that young, poor women, with low levels of formal education are the least likely of any group to find secure employment in the formal sector. Lack of formal employment opportunities for women influences their families' decisions on how long to keep paying for their education. Parents' awareness that there will be no jobs available for their girls once they graduate reduces the incentive to keep them in school. Local initiatives for the creation of formal employment opportunities, and investment in work skills, focus almost exclusively on young men because they are expected to be the primary income earners once they are married. Despite the normative gender expectation that men will be the main bread-winners, the reality for many poor families is that women must work in the most menial and poorly paid jobs to ensure their subsistence. The attitudes towards paid work expressed by the teenage mothers in this study indicated that if they could find fairly paid work in the formal sector, most would choose to work. Promoting young women's right to participate in formal employment - and to equal employment opportunities with their male peers - is likely to delay marriage and subsequently early child bearing.

Numerous human rights declarations uphold the right to marry. At the same time, the United Nations Convention on the Rights of the Child (1990) asserts that early marriage (before age 18) contradicts the rights and interests of children. Under Indonesian national law the minimum legal age of marriage for women is 16 , and for men it is 18 , despite the fact that the health risks of early parenthood are greater for women than for men. Recent human rights reports and activists in Indonesia have called for the minimum age of marriage to be made the same for both sexes, many now understand the younger legal age of marriage for women as a form of institutionalized gender discrimination (Bennett and Andajani-Sutjahjo 2007). However, for the minimum legal age of marriage to have any real meaning for people such as the Sasak in Lombok it needs to be accepted and adopted by religious authorities and community leaders, as marriage for poor villagers is largely a religious affair, not a state-based affair. If later marriage is to be promoted at the grass roots level, there needs to be an understanding of what it means locally to be a child or an adult. For Sasak girls, childhood ends when they become mothers, not when they turn 18. Achieving gender equality in the minimum age of marriage will assist in delaying marriage and childbirth for women, but it will only be achieved when local social and religious customs are supportive of this change.

\section{THE SYNERGY OF EARLY MARRIAGE AND ADOLESCENT MOTHERHOOD}

Having established why young Sasak women marry early and how early marriage is connected with the neglect of young women's rights, the next question that requires examination is: Why do young Sasak women seek to reproduce as soon as they marry? All of the young mothers in this study were 
adamant that their first child was both planned and wanted. Women and their husbands typically have intense emotional longing for a child as soon as they marry. In Sasak society, a woman's identity is completed when she becomes a mother and motherhood is understood as central to womanhood. In the words of Ika, a young mother aged 18: "perempuan tidak lengkap tanpa anak" (a woman is incomplete without a child). In addition to completing a woman's identity, a child gives a woman a solid emotional anchor and ally in her husband's family home where she is initially an outsider due to patrilocal residence patterns. It is expected by young people, their families, and their community, that a new couple will reproduce quickly. Newlyweds who delay having children are likely to attract negative gossip regarding their fertility and sexual relationship.

Adding a child to the family consolidates both a new marriage and extended family ties. Young mothers described the arrival of a baby as important for "tightening the ties between them and their husband". This is particularly salient in Lombok because Sasak marriages often occur before couples are well acquainted. It is not uncommon for couples to have known one another for only a matter of days or weeks before an elopement occurs. From a woman's point of view, pregnancy and the arrival of a child deters men from looking elsewhere and makes divorce less likely. Men believe that women are less prone to returning home to their mothers in response to marital discontent once the couple share a child. A grandchild integrates a new wife more intimately with her in-laws, as she is no longer merely an extra dependant. Her reproductive contribution is viewed as a valuable and productive role in the extended family. The majority of young mothers living with their in-laws described their relationship with their husband's family as semakin dekat (closer) or semakin sayang (warmer or more affectionate) after having their first baby.

All of the women I spoke with were unaware of any serious health risks related to early pregnancy and childbirth for either mother or child. While there are numerous social and emotional advantages of having a child soon after marriage, there also appears to be little awareness of the possible negative health consequences of doing so. When motherhood is a highly valued and normative social role and identity, and alternative roles and opportunities for young women are seriously limited due to poverty, there is no apparent incentive for delaying motherhood.

\section{THE HEALTH OF YOUNG SASAK MOTHERS AND THEIR CHILDREN}

The health risks for babies born to adolescent mothers are widely documented, and include higher rates of: infant mortality and morbidity; still births; low birth weight; and preterm deliveries (McCauley et al. 1995). Among the 31 children born to the women in this study, three babies were stillborn and their mothers were still grieving at the time of research. There was also one neonatal death, the cause of which was unknown to the mother. In the absence of any alternative explanation, she blamed herself. Two babies had been 
delivered prematurely and one had survived, although he was too immature to breastfeed. Fourteen young mothers described their babies as too small or as being under 2.5 kilograms at birth. Three of these women's babies had been born with serious disabilities, including intellectual disability, deafness and a missing limb. All the children born with disabilities were living with and cared for by their parents, and none had received adequate medical care at the time of research. ${ }^{7}$ While this research was qualitative, and as such cannot draw conclusions about prevalence in the wider community, the high occurrence of poor birth outcomes and compromised infant health is consistent with the findings of larger quantitative studies on children born to adolescent mothers (Gilbert et al. 2004; Chen et al. 2006).

Numerous studies have found that early motherhood is related to a higher likelihood of maternal mortality, prolonged labour associated with incomplete pelvic growth, fistula or vaginal tearing during birth, hypertension, and anaemia (McCauley et al. 1995). Younger mothers have also been found to be at greater risk of unsafe abortions and are thought to be less likely to receive prenatal care than more mature mothers (Choe, Thapa, and Achmad 2001). The reproductive health issues reported by the young mothers I interviewed included: severe symptoms of morning sickness for 15 women, often causing inability to eat; prolonged labour (over 12 hours and up to 36 hours) for 10 women; and 14 women reported acute symptoms of anaemia or chronic energy deficiency both during pregnancy and postpartum. None of the young mothers reported attempting induced abortion, but two reported experiencing early miscarriages in their first trimester. It is indisputable that the maternal health status and experiences of this group of young mothers is poor and that young mothers clearly require targeted assistance aimed at improving their maternal health. However, it is not plausible to conclude that the age of the mothers in this study was the sole or primary cause of their poor health. This is because of significant confounding factors including: poverty; high rates of anaemia and poor nutrition; the low educational attainment of "mothers"; and the absence of parallel data collected from older mothers in these communities.

While the health data presented above indicate that many young Sasak mothers experience significant suffering in relation to their maternal health, the study did not reveal any barriers to accessing maternal health services. None of the young mothers reported any difficulty accessing prenatal care. The majority attended monthly checkups from around the end of their first trimester either at puskesmas (primary health clinics) or posyandu (monthly maternal and child health clinics) held within villages. The 23 mothers interviewed had all attended prenatal care and received the minimum standard of four prenatal checkups (known as K4) ${ }^{8}$ set by the GOI. Young mothers felt confident requesting information from bidan, often inquiring

7 Before leaving Lombok at the end of this field trip, I was assisted by the CBO Korporasi Annisa to establish a health advocacy fund to finance the required health care for these three children.

8 " $\mathrm{K}$ " from Indonesian kunjungan 'visit to the doctor', $\mathrm{K} 4$ refers to the fourth visit. 
about the development of their babies and asking for advice on what to eat while pregnant. Seventeen out of 23 women had taken the recommended vitamin supplements during pregnancy. Ironically, those women who did not take pregnancy vitamins were not attending free clinics, or did not have kartu miskin (concession cards for the poor). In this instance, the choice not to attend free government services, but to pay for private services, actually resulted in these women missing out on important nutrients during pregnancy. All 28 of the women in this study reported having delivered their babies either with government-trained midwives or with doctors present, and none had home births.

Based on the experiences of women in this study, it appears that being young does not necessarily deter mothers from attending appropriate maternal health services. I believe this is in part due to recent improvements in the quality and accessibility of maternal health services in West Lombok, and also reflective of the fact that is not generally viewed as socially problematic for adolescent women to be pregnant in these communities provided that they are married. There is a relative absence of stigma associated with early pregnancy for young married women, which is in direct contrast to the extreme stigma attached to premarital pregnancy for single women (Bennett 2001). Previous research conducted in NTB in the late 1990's found that there was a dislike of bidan and a preference for seeking maternal care from belian (traditional birth attendants) or doctors (Hull et al. 1999). However, women in this study indicated that they were very comfortable with bidan as providers of pre- or postnatal care and as birth attendants. Five women also reported visiting doctors (all male) during their pregnancies, and had found bidan to be more willing to answer questions and to give less rushed examinations than doctors. In this region of West Lombok at least, it appears that bidan have become increasing integrated into and accepted by Sasak communities, and are now viewed by many women as their preferred maternal health providers.

While all young mothers interviewed said they enjoyed the check-ups and felt relieved to be assured that their pregnancies were normal, they did not receive any information about the process of childbirth during prenatal care. All would have liked more information about pregnancy and childbirth before becoming pregnant. Not a single young mother could describe any of the health risks associated with early pregnancy and childbearing for mothers or babies. During prenatal check-ups midwives had informed several women that they should not have become pregnant before the age of 20. This instruction from midwives was obsolete as it was given to women who were already pregnant. Young women felt that the advice was condescending or akin to be chastised, and their response was simply to remain silent. Young mothers reported that no health-based rationale for avoiding early pregnancy had been explained to them by midwives. 
THE RIGHTS TO HEALTH INFORMATION, FAMILY PLANNING, AND MATERNAL HEALTH

Young Sasak women's right to health information and to information about their reproductive and sexual health in particular, falls starkly short of the ideal. A Human Rights and Maternal Health Survey conducted in NTB with 1,004 married women in 2007 reported that $95 \%$ of women informants married before 18 years of age had never received formal reproductive sex education (MOH 2008). This survey also revealed that less than $10 \%$ of women married by the age of 18 felt they had enough knowledge of human reproduction at marriage (MOH 2008). Among the group of young mothers who participated in my ethnographic research, none was able to name any of the health risks for women associated with early motherhood, nor were they able to describe any of the associated health risks for babies born to adolescent mothers. Young mother's lack of knowledge about the risks connected with early pregnancy was not alleviated by their interaction with maternal health services. My findings indicate that poor young Sasak mothers rarely possess the information required to allow them to understand and subsequently assess the many risks associated with early pregnancy. The failure to recognize young women's right to reproductive health information fundamentally undermines their ability to make informed choices. If young women's right to information was met, they may choose to delay pregnancy in order to avoid the substantial risks to themselves and their babies. The desire to have healthy, strong babies with a high chance of survival was universally expressed by adolescent mothers in this study, and such a desire indicates great potential for young women to make different choices if they believe those choices are in the best interests of their children.

Adequate access to safe contraception is central to the prevention of pregnancy, and state sponsored family planning is in principle supplied free of charge to married Indonesian couples. However, it is not legal to supply contraception to unmarried individuals in Indonesia. Newly married young women are also in a particularly vulnerable position in relation to accessing family planning as contraception at the village level is typically accessed via bidan or health kader (volunteers) who visit women at their own discretion. The assumption that newlyweds will immediately attempt to conceive a child is so entrenched that adolescent wives are overlooked by those who supply free contraception at the village level. None of the young mothers in this study had used contraception prior to the birth of their first child, and all had been offered contraception for the first time during their postpartum visit from midwives. Every young woman in this group had keenly accepted the contraceptive method offered by their bidan postpartum. Several teenage mothers explained that they were keen to delay second pregnancies in order to give their babies as much attention as possible, while others noted that economic hardship meant they felt unable to support further children.

In some parts of Lombok, husband approval for women to use contraception is requested at puskesmas, a practice that undermines women's rights to family 
planning and reproductive autonomy. Ironically, the local perception that contraception is unnecessary for women until they have a child contradicts the very notion of planning a family. Ensuring that all women's rights to use family planning - regardless of age, parity, or husband approval has the potential to provide many more women with the true choice of delaying the birth of their first child.

Women also have the right to comprehensive maternal health care regardless of their age and marital status. Comprehensive maternal health requires that women have adequate information, access to vitamins and supplements, relevant immunizations, and a reasonable level of health, including not being anaemic prior to pregnancy. However, the first contact with maternal health services for all adolescent mothers in this study was when they were three to four months pregnant. While the system failed to connect with women before pregnancy, it did provide a decent standard of maternal health care after initial contact was made. All young mothers received their standard prenatal care (a minimum of four visits), and all received at least one postpartum visit during which family planning was offered. Their decisions on where to give birth (all had delivered at puskesmas or hospital) were reportedly made in consultation with their families. None of the women reported having home births and all had skilled birth attendants present at delivery. Thus, age did not appear to prevent these young mothers from accessing pre- and postnatal care, or from delivering with skilled attendants. However, none of the young women felt they had enough information about the actual process of childbirth before they delivered. In the opinion of young Sasak mothers, local maternal health services are functioning adequately, they are competent enough. However, when asked to do so adolescent mothers did offer a critique of maternal health services. The main concerns voiced were the need to engage with young wives sooner - prior to pregnancy, and the need to provide more comprehensive information on pregnancy and childbirth.

\section{CONCLUSION: THE RIGHT TO NON-DISCRIMINATION}

In this article, I have argued that early marriage and adolescent motherhood persists among poor Sasak women in Lombok due to the endemic poverty that dramatically reduces their educational and employment opportunities and leaves them with no other socially legitimate roles and identities besides marriage and motherhood. I have also demonstrated how Sasak marriage customs and dominant cultural constructions of female sexuality support the practice of early marriage for women, and how, in turn, adolescent marriage is typically closely followed by early childbearing. These qualitative findings mirror those of recent quantitative analyses (based on 2007 DHS data), indicating that young women understand the causes of their early marriages and early motherhood in a manner that is compatible with demographic analyses of causality. Both qualitative and quantitative perspectives confirm that limited formal education for girls, poor employment opportunities, as well as poverty and low levels of development, propel girls into early marriage. 
It is important that this evidence-based understanding of why poor women marry young is given precedence when designing interventions to early marriage and adolescent motherhood. As iterated above, it is time for a shift away from blaming adolescent women as individuals for their difficult life circumstances, and towards a clear acknowledgement that the responsibility for preventing early marriage and delaying childbirth should be a shared one.

The proceeding discussion has also highlighted how many of the popular stereotypes associated with early marriage and adolescent motherhood do not hold true for poor Indonesian women, who have a much greater tendency to marry earlier then their middle class or elite counterparts. It is evident that local and pan-Indonesian values that revere motherhood as a social role, and that also insist that women's sexuality can only be appropriately expressed within marriage support early marriage. Thus, the popular claim that early marriage and teenage pregnancy are caused by the intrusion of foreign "Western values" has no salience in this instance. The notion that early marriage is the result of free courtship between the sexes is also faulted in communities where women's pre-marital courtship is still highly censored. Finally, popular assumptions that girls who marry young necessarily fall into the social category of victims, or are associated with disease and sexual stigma, are again irrelevant in communities where early marriage remains normative and therefore is not innately problematized by either young girls or their families.

My analysis of data collected from young Sasak mothers has also shown how their understandings of, and choices in relation to, early marriage and teenage motherhood intersect neatly with a human rights framework for understanding early marriage and adolescent motherhood. The right to nondiscrimination in health care means that no one should be disadvantaged because of who they are. The discussion above has clarified that young Sasak mothers in this study did not primarily experience discrimination on the basis of their age. Rather, it found that young women experienced discrimination on the basis of their socio-economic class and their gender. Poverty and low social status increases the chances of disadvantage through: early school leaving; very poor job opportunities; and realistically modest limited life aspirations. These factors coalesce to encourage early marriage and early child bearing, which in turn increases the health risks for mothers and babies. Consequently, we can conclude that protecting girls and young women's rights to maternal health and to non-discrimination in health care requires a holistic approach that aims to promote women's rights to: formal education, health information, equal employment opportunities, family planning, and gender equality in the minimum age of marriage and in relation to marriage customs. Reproductive rights are a subset of human rights and cannot be guaranteed if those wider human rights are not achieved.

The insights offered in this article on the aetiology of early marriage and adolescent motherhood within poor Indonesian communities also highlight key protective factors that could realistically form the basis of intervention 
programs. First, promoting longer participation in formal education for girls, and increasing the proportion of girls completing senior secondary school would very likely have a positive impact on reducing the incidence of early marriages in these communities. Second, the generation of ongoing employment opportunities for young women in the formal labour sector is also likely to delay marriage and possibly even the birth of children for young married women. Third, providing adequate health information regarding the risks of early pregnancy for women and their babies may well allow young couples to make more informed choices about when they start having children. Finally, the timely provision of free family planning counselling and contraceptives to engaged and newlywed couples will give them the actual choice of being able to delay pregnancy. Each of these suggestions is compatible with a human rights approach and with the stated health and development goals and policies of the GOI. Thus, they represent a realistic path to what so many of my young informants had hoped for a brighter future.

\section{REFERENCES}

Beazley, H. 2003. "Voices from the margins; Street children's subcultures in Indonesia children's geographies", Advancing Interdisciplinary Understanding of Younger People's Lives 1(2): 181-200.

Beazley, H. 2008. "'I love dugem'; Young women's participation in the Indonesian dance party scene", Intersections; Gender and sexuality in Asia and the Pacific. Issue 18, October. [Http://intersections.anu.edu.au/issue18/ beazley.htm.]

Beazley, H. 2010. "Multiple identities, multiple realities; Children who migrate for work in Indonesia and Vietnam". Paper, Inter-Asia Roundtable; Transnational Migration and Children in Asian Contexts, Singapore, 2-3 August.

Bennett, L.R. 2001. “Single women's experiences of premarital pregnancy and induced abortion in Lombok, Eastern Indonesia", Reproductive Health Matters, 19 (17): 37-43.

Bennett, L.R. 2002. "Modernity, desire and courtship; The evolution of premarital relationships in Mataram, Eastern Indonesia", in: L. Manderson and P. Liamputtong (eds), Coming of age in South and Southeast Asia; Youth, sexuality and courtship, pp. 96-112. London: Routledge.

Bennett, L. R. 2005. Women, Islam, and modernity; Single women, sexuality, and reproductive health in contemporary Indonesia. London/New York: Routledge Curzon.

Bennett, L.R. and S. Andajani-Sutjahjo. 2007. Mapping human rights in maternal and neonatal health; A report on provincial laws, policies and plans, and primary data from 4 districts in NTB/NTT. Jakarta: MOH and GTZ. [Research report prepared for stakeholder consideration.]

Biddlecom, A., R. Gregory, C. B. Lloyd, and B. S. Mensch. 2008. “Associations between premarital sex and leaving school in four Sub-Saharan African countries", Studies in Family Planning 39: 337-350. 
Blackburn. S. and S. Bessell. 2007. "Marriageable age; Political debates in early marriage in twentieth-century Indonesia", Southeast Asia Program Publications Cornell University 63: 107-141.

BPS (Badan PusatStatistik) and Macro International. 2008. Indonesia demographic and health survey 2007. Jakarta/Calverton: BPS and Macro International.

Chen X. K., S.W. Wen, N. Fleming, K. Demissie, G.G. Rhoads, and M. Walker. 2006. "Teenage pregnancy and adverse birth outcomes; A large population based retrospective cohort study", International Journal of Epidemiology 36 (2): 368-373.

Choe, M. S. Thapa, and S. Achmad. 2001. "Early marriage and childbearing in Indonesia and Nepal", East-West Centre Working Papers 108 (15). [Http:/ / www.eastwestcenter.org/sites/default/files/private/POPwp10815.pdf.]

Desriani, D. 2011. “Determinants of teenage motherhood; Evidence from the 2007 Indonesia demographic and health survey", Paper, Claiming sexual and reproductive rights in Asian and Pacific societies; The 6th Asia Pacific Conference on Reproductive and Sexual Health and Rights, Yogyakarta 19-22 October.

Gilbert, W., D. Jandial, N. Field, P. Bigelow, and B. Danielsen. 2004. "Birth outcomes in teenage pregnancies", Journal of Maternal Fetal Neonatal Medicine 16 (5): 265-270.

Grace, J. 1997. Health development and Sasak women; A political and practical analysis of medical intervention in rural East Lombok, Indonesia. PhD Thesis, Curtin University.

Grant, M. J. and K. K. Hallman. 2008. "Pregnancy-related school dropout and prior school performance in KwaZulu-Natal, South Africa", Studies in Family Planning 39: 369-382.

Harding, C. 2007. "Adolescent sexual and reproductive health in Indonesia; Investing in the future?". Unpublished honours thesis, University of Western Australia.

Harding, C. 2008. "The influence of the 'Decadent West'; Discourses of the mass media on youth sexuality in Indonesia", Intersections; Gender and sexuality in Asia and the Pacific 18 (October). [Http://intersections.anu. edu.au/issue18/harding.htm.]

Hull, T. H., D. Widayatun, A. Raharto, and B. Setiawan. 1999. “Neither dukun nor doctor; Some problems of the village midwife programme in Eastern Indonesia", Development Bulletin 48: 17-20.

Jakarta Globe. 2010. "Pregnant teens still face stigma, isolation, even death", 7 June. [Http:/ / www.thejakartaglobe.com/home/pregnant-teens-stillface-stigma-isolation-even -death/379112\#Scene_1, accessed on 9-1-2012.]

Jones, G., and B. Gubhaju. 2008. “Trends in age at marriage in the provinces of Indonesia", Asia Research Institute Working Paper Series 105. [Http:// www.ari.nus.edu.sg/docs/wps/ wps08_105.pdf.]

Jones, G. W. and P. Hagul. 2001. “Schooling in Indonesia; Crisis-related and longer-term issues", Bulletin of Indonesian Economic Studies 37: 207-231.

Judd, M. 1980. "The sociology of rural poverty in Lombok, Indonesia". Unpublished PhD Thesis, University of California. 
Luvaas, B. 2009. “Dislocating sounds; The deterritorialization of Indonesian Indie pop", Cultural Anthropology 24(2): 246-279.

Luvaas, B. 2010. "Designer vandalism; Indonesian Indie fashion and the cultural practice of cut 'n' paste", Visual Anthropology Review 26(1): 1-16.

Mc Cauley, A. P., C. Salter, K. Kiragu, and J. Senderowitz. 1995. “Meeting the needs of young adults", Popul Rep J(41): 1-43.

$\mathrm{MOH}$ (Indonesian Ministry of Health). 2008. Measuring the fulfillment of human rights in maternal and neonatal health; Report on provincial and district laws, regulations, policies, and standards of care. Mataram: $\mathrm{MOH}$, Provincial Health Offices of West Nusa Tenggara and East Nusa Tenggara and GTZ.

Nasril, R. and O. Samosir. 2011. "Factors influencing teenage motherhood in Indonesia". Paper, Claiming sexual and reproductive rights in Asian and Pacific societies; The 6th Asia Pacific Conference on Reproductive and Sexual Health and Rights, Yogyakarta 19-22 October.

Nilan, P. 2008. "Muslim media and youth in globalizing Southeast Asia", Media Consumption and Everyday Life in Asia: 45-58.

Nilan, P., L. Parker, L.R. Bennett, and K. Robinson. 2011. “Indonesian youth looking towards the future", Journal of Youth Studies 14(6): 709-728. [Http:/ / dx.doi.org/10.1080/ 13676261.2011.580523.]

Parker, L. 1997. "Engendering school children in Bali", The Journal of the Royal Anthropological Institute, incorporating 'Man' (JRAI) 3 (3): 497-516.

Parker, L.M. 2009. “Religion, class, and schooled sexuality among Minangkabau teenage girls", Bijdragen tot de Taal-, Land- en Volkenkunde 165(1): 62-94.

Platt, M. 2012. "It's already gone too far; Women and the transition into marriage in Lombok, Indonesia", The Asia Pacific Journal of Anthropology 13: 76-90.

Prasetya, L. and G. Dasvarma. 2011. “Factors influencing age at marriage and ideal number of children among the youth and adolescents of in Indonesia; Evidence from the Indonesia youth and young adult reproductive health survey 2007". Paper, Claiming sexual and reproductive rights Asian and Pacific societies; The 6th Asia Pacific Conference on Reproductive and Sexual Health and Rights, Yogyakarta, 19-22 October.

Rusman, R., E. Djohan, and T.H. Hull. 1999. They simply die; Searching for the causes of high infant mortality in Lombok. Jakarta: Center for Population and Manpower Studies, Indonesian Institute of Sciences.

Safika, I. 2009. "The Influence of sex work venues on condom use among sex workers in Senggigi, Indonesia". Unpublished PhD Thesis, University of Illinois.

Suryadarma, D., A. Suryahadi, and S. Sumarto. 2005. The measurement and trends of unemployment in Indonesia; The issue of discouraged workers. Jakarta: SMERU Research Institute Working Papers. [Http://saber. eastasiaforum.org/testing/eaber/sites/default / files/documents/ SMERU_Suryadarma_2005_03.pdf.]

Satu Dunia. 2009. "Pregnant teenagers, the consequences of free sex, high risk of spreading HIV", 2 April. [Http://www.satudunia.net/content/ remaja-hamil-akibat-seks-bebas-berisiko-berat-tertular-hiv.] 
Svanemyr, J., V. Chandra, C. Sigurdson Christiansen, and M. Mbizvo. 2012. "Preventing child marriages; First international day of the girl child 'my life, my right, end child marriage'", Reproductive Health, 9(31). [Http:// www.reproductive-health-journal.com/content/pdf/ 1742-4755-9-31. pdf.]

United Nations Children's Fund (UNICEF). 2004. Commercial sexual exploitation of children in Surakarta (Central Java) and Indramayu (West Java), Indonesia; Participatory research with children. Jakarta: UNICEF.

United Nations Development Program (UNDP). 2007. Human development report 2007/2008; Fighting climate change; Human solidarity in a divided world. New York: Palgrave Macmillan.

Wright-Webster, T. 2010. "Pergaulan bebas and gendered youth culture in Yogyakarta, Indonesia“. Unpublished PhD thesis, University of Western Australia. 